\title{
Ukraina: Grenselandet mellom øst og vest
}

\author{
Morten Strand \\ Oslo: Cappelen Damm 2015 \\ 315 sider. ISBN 9788202481995
}

Anmeldt af Jonas Gejl Pedersen [Ph.d.-stipendiat, Institut for Statskundskab, Aarhus Universitet, Danmark, gejl@ps.au.dk]

I Ukraina: Grenselandet mellom øst og vest har Morten Strand - med Ukraine-krisen, Ruslands koldkrigsrevisionisme og sin »kjærlighet til Ukraina og menneskene der « (s. 11) som sine præmisser - sat sig for at undersøge, " når og hvordan en ukrainsk identitet ble skapt« (s. 9). Således blander Strands bog sig i den aktuelle diskussion om Ukraines status som suveræn stat og eksistensen af en særegen ukrainsk identitet. Strands bog er dermed et kærkomment bidrag til det væsentlige identitetsaspekt, der kun er blevet behandlet sparsomt i den eksisterende litteratur om konflikten mellem Rusland og Ukraine.

Strands undersøgelse af den ukrainske identitet tager udgangspunkt i Vladimir I’s Kievrus og dets kristning i 988. Derpå tages læseren på en rejse gennem mere end 1000 års ukrainsk historie frem til demonstrationerne på Maidan-pladsen, der kulminerer med Viktor Janukovitjs flugt i begyndelsen af 2014. Endvidere behandles annekteringen af Krim og kampene mellem separatister og regeringstropper i det østlige Ukraine. Kapitlerne omhandlende Orangerevolutionen og Ukraine-krisen er forsynet med udførlige uddrag fra Strands egne reportager herfra til det norske Dagbladet.

Med kyndig fortællerevne og et uhøjtideligt sprog formår Strand at fastholde læseren og manøvrerer tilmed elegant udenom historiske trivialiteter og kuriositeter, der ud fra denne læsers erfaring udgør de væsentligste faldgruber for kronologiske fortællinger som Strands. Endvidere gøres læseren løbende opmærksom på, hvordan centrale historiske personer og begivenheder bruges af både russere og ukrainere til at legitimere nutidige handlinger. Således har Strand et godt øje for relevante eksempler på både politiske og identitetsmæssige konsekvenser af nutidens brug af historien. Et eksempel herpå er, hvordan Vladimir Putin - i sin tale den 4. december 2014-bruger Vladimir I's kristning i Khersones til at legitimere annekteringen af Krim, hvis hellige betydning for russerne sammenlignes med, hvad Tempelhøjen er for jødedommen og islam. Et andet relevant eksempel er, hvordan både ukrainere og russere bruger Stepan Bandera som symbol på henholdsvis en legitim ukrainsk frihedskamp - mod en russisk overmagt - og som belæg for beskyldningerne om Maidan-regeringens fascistoide værdigrundlag. Således er Strand ikke påholdende med sin viden om både Ukraines og Ruslands historie, eller hvordan forskellige tolkninger af Ukraines og 
Ruslands historie - navnlig hvor de overlapper - gennem tiden har udgjort kimen til både samarbejde og konflikt mellem landene.

For at vende tilbage til Strands oprindelige spørgsmål - hvornår og hvordan den ukrainske identitet blev skabt - og besvarelsen heraf, så finder denne læser sig mindre taget $\mathrm{i}$ hånden af Strand end ellers. Når Strand i slutningen af hvert kapitel konkluderer, om Ukraine blev mere ukrainsk i den behandlede periode, er overensstemmelsen mellem analyse og konklusion ofte mindre klar. I umiddelbar forlængelse af bogens problemstilling anfører Strand, at netop sproget er en vigtig del af det politiske drama i nutidens Ukraine, ligesom det i det efterfølgende kapitel anføres, at religion er en væsentlig identitetsbærer i nutidens Rusland. Denne læser efterlyser imidlertid en eksplicit definition af Strands forståelse af kernebegrebet identitet. Uden en klar indledningsvis definition af Strands identitetsbegreb får læseren sværere ved at forstå og forholde sig til Strands analyse - der så forekommer mindre stringent - og dermed også, hvad Strands efterfølgende konklusioner baseres på.

Flere af bogens konklusioner foretages på baggrund af en vurdering af, om og i hvilken udstrækning det talte og skrevne ukrainske sprog var accepteret og udbredt i den behandlede periode. Endvidere synes spørgsmålet om udviklingen af en selvstændig ukrainsk identitet centralt for de konklusioner, Strand når, men læseren indvies imidlertid ikke i Strands rationale for at inddrage stats- og nationsdannelse i en bog, der har ukrainsk identitet som sit primære analytiske genstandsfelt. Således blandes spørgsmålet om ukrainsk identitet uden videre sammen med udviklingen af en selvstændig ukrainsk nations- og statsdannelse. En sådan sammenblanding er imidlertid ikke uproblematisk. Udviklingen af en selvstændig stats- og nationsdannelse har således ikke nødvendigvis nogen betydning for spørgsmålet om identitet. Identitet er ikke nødvendigvis knyttet til en given stat eller nation, ligesom forståelser af, hvad der konstituerer staten og nationen, ikke nødvendigvis er overlappende. Uden Strands eksplicitte stillingtagen hertil er læseren overladt til sig selv. De fortsatte kampe i Østukraine demonstrer således, at hvad der forstås ved en ukrainsk stat, nation og identitet i Donétsk og Luhánsk ikke nødvendigvis er foreneligt med, hvad der forstås herved i Kiev eller Lviv.

Mest pudsig forekommer dog konklusionen i kapitlet, der behandler Holodomor. Her anvendes en kvantitativ forståelse af identitetsbegrebet som grundlag for Strands konklusion: "Det var blitt færre ukrainere, og sånn sett var Ukraina blitt mindre ukrainsk« (s. 133). I det følgende kapitel om Anden verdenskrig tillægges den kvantitative dimension - som følge af det høje ukrainske tabstal - igen en negativ betydning for ukrainsk identitet, omend Strand tillægger ukrainernes splittelse over erindringen af Anden verdenskrig en større betydning. Igen kunne en eksplicit begrundelse for, hvorfor den kvantitative dimension inddrages - og hvilken vægt den tillægges - have hjulpet læseren.

Morten Strands Ukraina: Grenselandet mellom øst og vest efterlader et overvejende positivt indtryk hos denne læser. Foruden Strands kyndige fortælleevne er forståelsen af historiebrugens betydning og behandlingen af Ukraines tidlige historie blandt de væsentligste kvaliteter ved Strands bog. Den akademiske læser vil formodentlig savne en mere klar definition på det identitetsbegreb, Strand anvender som udgangspunkt 
for sin analyse af den ukrainske identitets opståen og udvikling. Netop identitetsbegrebet er yderst svært at håndtere, idet det rummer så umådeligt mange facetter, hvorfor studier heraf bør stille særligt skærpede krav til definitorisk klarhed. Således kunne Strand med fordel have gjort det mere klart, hvordan identitet defineres og undersøges empirisk. Analysen af og de løbende konklusioner på, når og hvordan den ukrainske identitet udvikles, kommer dermed til at fremstå henholdsvis mindre stringent og følgelige.

Strand foregiver imidlertid ikke at have skrevet en videnskabelig afhandling om ukrainsk identitet. Bedømt på sine egne præmisser er bogen derfor anbefalelsesværdig til enhver, der på en indbydende og lettilgængelig facon ønsker at øge sin viden om Ukraines historie og historiebrugens muligheder, men også sin forståelse af, hvordan identitet kan være udgangspunkt for både samarbejde og konflikt mellem mennesker og stater. 